\title{
Taking to video-assisted thoracoscopic surgery like ducks to water
}

The Lung Center of the Philippines (LCP) is the only tertiary medical facility for chest and other respiratory diseases in the Philippines. From September 27 to 29, 1993, a year after the first reported video-assisted thoracoscopic surgery (VATS) lobectomy, the Endoscopic and Laparoscopic Surgeons of Asia (ELSA) held the first VATS workshop in Asia at the LCP with Professors Robert McKenna and Rodney Landreneau as course directors. One of the trainees then was Professor Anthony Yim of Hong Kong who went on to become one of the world's leading minimally invasive thoracic surgeons.

After this seminal event, VATS took hold at the LCP with hundreds of minimally invasive thoracoscopic procedures being performed short of the major resective procedures. A fire which razed $80 \%$ of the hospital to the ground in May 16, 1998 stopped the burgeoning of VATS, only to be resumed 5 years later with the partial rebuilding of the hospital.

During my term as head of the hospital in 2011, the health secretary (a transplant surgeon) provided funds for a minimally invasive operating room equipment. This resulted in an exponential rise in advanced VATS procedures with the local thoracic surgeons taking to the procedure like ducks to water. so much so that around $80 \%$ of thoracic surgical procedures are now done through VATS. One junior consultant thoracic surgeon was sent to the Prince of Wales Hospital in Hong Kong under the tutelage of Professor Calvin Ng to learn single port VATS. When he returned to the LCP, single port VATS again immediately took off such that majority of VATS procedures are now performed through a single port.

Other foreign thoracic surgeons also helped the LCP in its fledgling VATS program by delivering lectures, conducting workshops and performing live surgery in the Philippines, among them Professor Alan Sihoe who graced the first single port VATS symposium in the Philippines. Professors Thirugnanam Agasthian, Diego Gonzales-Rivas and others.

It would have been unthinkable a few years back for the Philippines to be hosting an international VATS conference, let alone an Asian Single Port VATS Symposium but Professor Calvin SH Ng should be thanked for making this a reality. Thus, this special issue on the 6th ASPVS is a testament to the efforts of everyone who helped in making minimally invasive thoracic surgery in the Philippines what it is today.

\section{Acknowledgments}

Funding: None.

\section{Footnote}

Provenance and Peer Review: This article was commissioned by the editorial office, Fournal of Visualized Surgery for the series "Dedicated to the 6th Asian Single-port VATS Symposium 2018". The article did not undergo external peer review.

Conflicts of Interest: The author has completed the ICMJE uniform disclosure form (available at http://dx.doi.org/10.21037/ jovs.2018.07.08). The series "Dedicated to the 6th Asian Single-port VATS Symposium 2018" was commissioned by the editorial office without any funding or sponsorship. JLD served as the unpaid Guest Editor of the series. The author has no other conflicts of interest to declare.

Ethical Statement: The author is accountable for all aspects of the work in ensuring that questions related to the accuracy or integrity of any part of the work are appropriately investigated and resolved.

Open Access Statement: This is an Open Access article distributed in accordance with the Creative Commons AttributionNonCommercial-NoDerivs 4.0 International License (CC BY-NC-ND 4.0), which permits the non-commercial replication and distribution of the article with the strict proviso that no changes or edits are made and the original work is properly cited (including links to both the formal publication through the relevant DOI and the license). See: https://creativecommons.org/licenses/by-nc$\mathrm{nd} / 4.0 /$. 


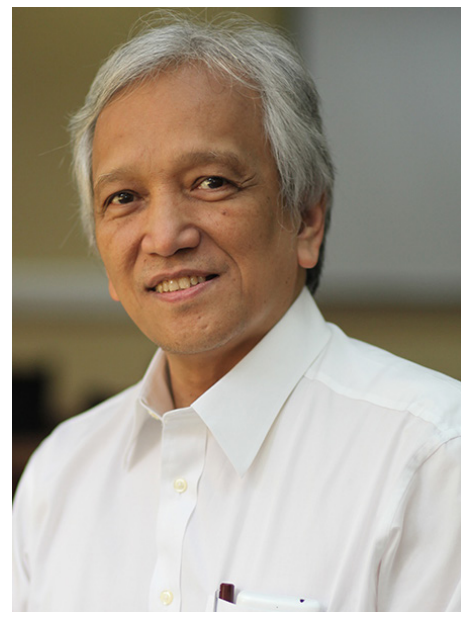

Jose Luis Danguilan

Jose Luis Danguilan, MD Lung Center of the Philippines, Quezon Avenue, Quezon City, Philippines. (Email: jdanguilan@gmail.com) Received: 07 November 2018; Accepted: 22 November 2018; Published: 23 November 2018. doi: $10.21037 /$ jovs.2018.07.08 View this article at: http://dx.doi.org/10.21037/jovs.2018.07.08

doi: 10.21037/jovs.2018.07.08

Cite this article as: Danguilan JL. Taking to videoassisted thoracoscopic surgery like ducks to water. J Vis Surg 2018;4:241. 